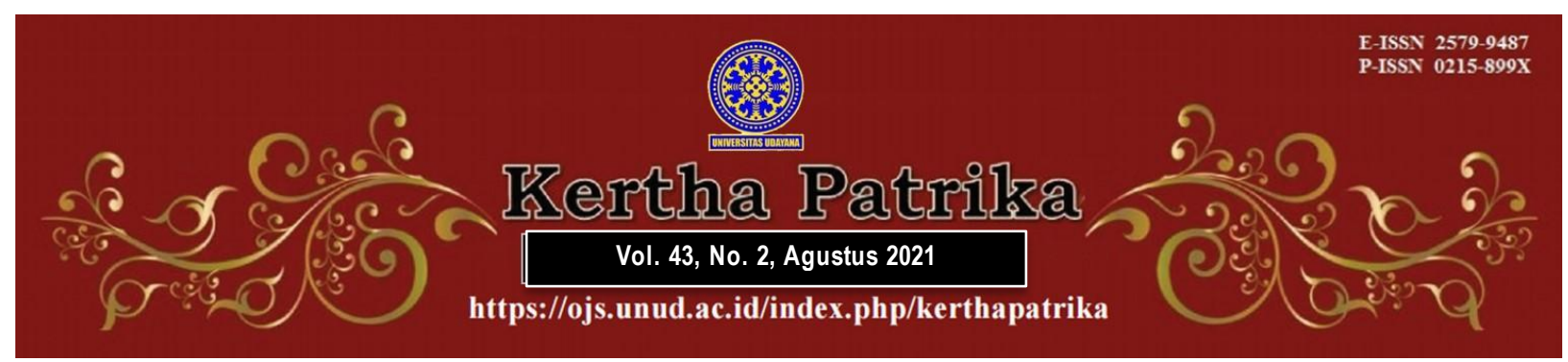

\title{
Government Immunity and Liability in Tort: The Case of Covid-19 Pandemic's Management in Indonesia
}

\section{Laras Susanti ${ }^{1}$}

${ }^{1}$ Faculty of Law, Gadjah Mada University, E-mail: susanti.laras@mail.ugm.ac.id

\begin{tabular}{l}
\hline Info Artikel \\
Submitted : $11^{\text {th }}$ October 2020 \\
Accepted : $21^{\text {st }}$ June 2021 \\
Published : $1^{\text {st }}$ July 2021 \\
Keywords: \\
Government; Tort; Liability; \\
Immunity; Covid-19; Indonesia \\
\\
Corresponding Author: \\
Laras Susanti \\
E-mail: \\
susanti.laras@mail.ugm.ac.id \\
DOI : \\
10.24843/KP.2021.v43.i02.p02 \\
\hline
\end{tabular}

\begin{abstract}
The Covid-19 pandemic has cost human lives and threaten the world's economy. Responding to this unprecedented history, governments are expected to take both public health and economic recovery actions. This article conveys analysis on how Indonesian courts might examine government tort cases on the government's liability in handling the pandemic. A normative juridical method is used to analyze primary and secondary legal sources. The writer finds that with the enactment of Law Number 30 of 2014 on Government Administration, a government concrete action is also an object to suing government before the state administrative court. Furthermore, the recent Supreme Court Regulation Number 2 of 2019 on Guidance Dispute Settlement Mechanism of Government Action and Competence to Adjudicate Government Tort governs that the state administrative court is the only court that has competence over government tort. As a result, claims of government tort submitted to the general court must be dismissed. In fact, this recent development created confusion on the side of justice seekers and judges as well that might affect the outcome of Covid-19 government tort claims. Studying previous government tort cases and focusing its exploration on the development of government immunity and liability, this article finds that Indonesian courts use Article 1365 Civil Code equipped with laws and regulations in administrative governance and specific fields legal frameworks to examine government tort cases. Even though such laws may state that the government may not be sued, the courts may use the Constitution of 1945 to establish a right to sue. During the Covid-19 pandemic, laws and regulations related to disaster and public health management along with the public interest principle must be examined to determine government tort.
\end{abstract}

\section{Introduction}

It started in Wuhan, China, a novel coronavirus named Covid-19 spread out around the world. By May 16, 2021, the virus infected 162 million people in 213 (two hundred thirty) 
countries. ${ }^{1}$ The International Monetary Fund predicted that a global recession caused by the pandemic is the worst since the 1930s Great Depressions. ${ }^{2}$

Likewise, in other countries in the world, the pandemic is a catastrophe to its societyand economy. By May 17, 2021, there were over 1,7 million positive cases, which caused 48 thousand deaths in Indonesia. ${ }^{3}$ The Ministry of Manpower predicts by the end of 2020, 5.5 million laid offs. ${ }^{4}$ Meanwhile, in March 2021, the Central Bank of Indonesia reported $93,2 \%$ small and medium enterprises were negatively affected by the pandemic. ${ }^{5}$

The pandemic has put the Indonesian government in a difficult position. It must take immediate, precise, and clear actions. A group of small and medium enterprises owners submitted a class action lawsuit claim to the Central District Court of Jakarta. They, the plaintiffs, argue the government has failed to take precautionary actions hence led to a more significant loss to Indonesia's society and economy.

The plaintiffs cite how Joko Widodo's administration omitted to acknowledge that the virus might be already transmitted in Indonesia and how dangerous the virus to human lives. They recalled the events when number of ministers joked about the pandemic, claiming that citizens must not worry too much. ${ }^{6}$ A paradox occurs when the government spent public fund for influencers to attract tourists, 7 a policy that contradicts to the World Health Organization (WHO) advises taking immediate actions to restrict the travels. In such a frustrating situation, on April 01, 2020, the plaintiffs submitted their lawsuit, asking the court to find the government liable for negligence; and therefore requesting 10 million rupiahs as a remedy. ${ }^{8}$ The government verbally responded to the lawsuit through its Presidential Special Staff for Law Affairs, stating that this non-

1 WHO. Retrieved from who.intl: https://covid19.who.int/?gclid=CjwKCAjwqIiFBhAHEiwA Ng9sznOyLBuTXz9p30IQMA4Eo85Xqx16Pb8EbQwLvb1kamfm00U-1kW6JBoCUUMQAvD BwE. Accessed on May 17, 2021.

2 Reuters Staff. (2020, June 24). IMF Predicts Deeper Global Recession due to Coronavirus Pandemic. Retrieved from Reuters: https://www.reuters.com/article/us-health-coronavirus-imfoutlook/imf-predicts-deeper-global-recession-due-to-coronavirus-pandemicidUSKBN23V1X8. Accessed on October 11, 2020.

3 Worldometers. Retrieved from worldometers.info: https://www.worldometers.info/ coronavirus/country/indonesia/. Accessed on May 17, 2021.

4 Akhlas, A.W. (2020, June 25). Crisis Like No Other Will Shrink Indonesia Economy. Retrieved from The Jakarta Post: https://www.thejakartapost.com/news/2020/06/25/crisis-like-no-otherwill-shrink-indonesias-economy-imf-forecasts.html. Accessed on October 11, 2020.

5 Saputra, D. (2021, March 19), Survei BI: 87,5 Persen UMKM Indonesia Terdampak Pandemi Covid-19. Retrieved from Bisnis.com: https://ekonomi.bisnis.com/read/20210319 19/1370022/survei-bi-875-persen-umkm-indonesia-terdampak-pandemi-covid-19. Accessed on March 17, 2021.

6 Garjito, D. (2020, March 4). Komunikasi Menkes Terawan Dikritik, 4 Pernyataan Soal Corona Jadi Sorotan. Retrieved from Suara.com: https://www.suara.com/news/2020/03/04 $\angle 101853 /$ komunikasi-menkes-terawan-dikritik-4-pernyataan-soal-corona-jadi-sorotan. Accessed on April 03, 2020.

7 Karunia, A.M. (2020, April 14). Luhut: Pemerintah Akan Segera Tarik Turis dari China, Korsel, dan Jepang. Retrieved from Kompas.com: https://money.kompas.com/read/2020/04/14 211200226/luhut-pemerintah-akan-segera-tarik-turis-dari-china-korsel-dan-jepang. Accessed on October 11, 2020.

8 Putri, Z. (2020, April 1). Pedagang UMKM Gugat Jokowi Rp 10 Miliar Buntut Penanganan Corona. Retrieved from Detik.com: https://news.detik.com/berita/d-4961584/pedagang-umkmgugat-jokowi-rp-10-miliar-buntut-penanganan-corona. Accessed on April 03, 2020. 
natural disaster was unforeseen and asked the plaintiffs to compare the suffering with what happened in other countries. ${ }^{9}$ This argument, later, is supported by Law Number 2 of 2020 concerning the Stipulation of Government Regulation in Lieu of Law Number 1 of 2020 concerning State Financial Policy and Financial System Stability for Handling the Corona Virus Disease 2019 (Covid-19) Pandemic and/or in the Context of Facing Threats That Endanger the National Economy and/or Financial System Stability Into Law. The law has received critiques for not only focusing more on economic response compared to public health actions, but also governing government immunity for civil and criminal cases. Specifically, the Law in Article 27 (2) states that any mandated government's institutions by this law cannot be sued in civil and criminal cases if maintaining good faith in their performance.

Both government's verbal response and the aforementioned law sparked a discourse on government immunity and liability. These issues have already been deliberated since a long time ago by scholars. In many countries, courts become a battlefield to test the discourse. Government liability in tort is different from private entities, "Unlike private tortfeasors, the government's objective is not profit maximization; it responds to political and not market discipline." 10 Rosenthal argues that the nature of government action isa political incentive to maximize political control over tax and spending is used to legitimize government immunity. ${ }^{11}$ Hence, the government has immunity since the beginning of the government actions to fulfil public interest. Furthermore, Rosenthal claims that the government does have the authority to conduct for public interest and decrease the potential loss of the public, accountability must be used to test the statutory immunity for discretionary functions. ${ }^{12}$

On the issue of legal standing, AV Dicey had clarified that the government can bea party before "ordinary court." 13 Citing to Dicey, Aronson argues that since the $19^{\text {th }}$ century, Australia had started to decrease the king's immunity. ${ }^{14}$ In common law system traditions, it is not enough to only test the government immunity from "common law duties of care law duties of care by reference to a distinction between 'policy' and "operational' issues." 15 Therefore, looking for a proper test is challenging and will be very categorical depending on the characters of the addressed government bodies. Aronson suggests shifting the focus directly to the role of the court to examine the

9 Respons Istana atas Gugatan Warga ke Jokowi Soal Corona. (2020, April 3). Retrieved from CNN Indonesia: https://www.cnnindonesia.com/nasional/20200403075252-32-489858/responsistana-atas-gugatan-warga-ke-jokowi-soal-corona. Accessed on April 03, 2020.

10 Rosenthal, L. (2007). A Theory of Government Damage Liability: Torts, Constitutional Torts, and Takings. University of Pennsylvania Journal of Constitutional Law, 9(3), 798. Retrieved from https:// papers.ssrn.com/sol3/papers.cfm?abstract_id=978833.

11 Ibid, p. 799-800.

12 Ibid.

13 Dicey, A.V. (1959). Introduction to the Study of the Law of the Constitution. London: MacMillan. pp. 193. As cited by Aronson, M. (2008). Government Liability in Negligence. Melbourne University Law Review, 32(1), 44. Retrieved from https://law.unimelb.edu.au/_data/assets/pdf_file/0008/1705769/32_1_2.pdf.

14 Ibid, p. 45.

15 Ibid, p. 56. 
negligence and ask further on what factors are become a hindrance in deciding, regardless of whoever the addressed government bodies. 16

Such development of thought above is hardly be seen in Indonesia. As the country rooted in the continental system, the existence of legislation is essential. Until now, it still relies on Article 1365 of the Indonesian Civil Code. Previously, the Indonesian legal framework governs the general court has the competence over government tort that uses Article 1365 of the Indonesian Civil Code to convict the government in tort. Meanwhile, the state administrative court adjudicates challenge to government decree. In responding to the new development of government adjudication by the state administrative court, the writer believes the only way to learn the discourse is by looking to court cases both adjudicated by the general court and state administrative court.

This article conveys analysis on the theoretical discourse of government immunity and liability in tort continued by on how the tort is governed by the Indonesian legal framework. It tries to offer a better understanding of how government tort has evolved in courts, thus, this article provides the comparison of practices in the examination of government tort by the general court and state administrative court. Finally, this research provides a specific analysis on the Covid-19 lawsuit case and how it might be examined by courts.

\section{Research Method}

It is a normative legal research that studies legal data including primary and secondary sources of law. Primary sources of law gained and analyzed for this researcharethe1945 Constitution of the Republic of Indonesia, a number of laws and regulations regarding judicial power, tort, and Covid-19 management this research also studied closely Supreme Court Regulation Number 2 of 2019 regarding government tort and several court decisions on government tort. Those primary sources of law were analyzed to understand how Indonesia's legal framework governs on government tort, government's liability and impunity. The secondary sources of law, such as scholarly articles are collected through identification of issues, such as tort, government immunity in tort, tort in Indonesia. The writer used arguments presented by the articles to analyze the issue in this paper. Further, as this research aimed to recommend how courts might examine Covid-19 government tort claim, the research analyzed the current transition of court competence, and it is a possible impact on the claim. All data are analyzed qualitatively. After analyzing all data, conclusions and recommendations were made.

\section{Result and discussion}

\subsection{Theoretic Discourse on Government Immunity and Liability in Tort}

Before going in-depth on how Indonesia's legal framework governs government tort liability and immunity, this article will briefly cover how the discourse developed globally. It compares two major legal systems globally: common law and continental system response to such matter.

As the law evolves together with society, scholarly debates and states' governances also develop overtimes. Historically, under the kings' leadership era, the legal maxim was

${ }^{16}$ Ibid, p. 82. 
king does not do wrong. The king's attributes are sovereign and independent. As a result, there were no possible cases against the kings; courts cannot exert their power over it. 17 Later, in a democratic government ship, the maxim was overthrown.

In the United States of America (U.S)., the maxim faces a democratic government, whereas the constitution limits executive and legislative power. ${ }^{18}$ Consequently, some courts use "wrongful act, neglect, or default" to examine states' liability. ${ }^{19}$ If the possibility to sue for liability is open, the next issue is when a suit against an officer is accepted as a suit against states. In England, the question is whether the act is served for public purposes or private entities. ${ }^{20}$

In the U.S., the Eleventh Amendment governed prohibition for federal courts to hear a certain type of cases against states. Another interpretation of the Amendment is state courts can object to examine claims against states if the suits were based on federal laws. ${ }^{21}$ Several notable cases were heard by the Supreme Court where it ruled to give immunity even to cases beyond the Eleventh Amendment. ${ }^{22}$ For example, in Alden v. Maine, 527 US 706 (1999), in the issue of labour violation, a group of probation officers sued the State of Maine. The Supreme Court decided that "States are immune from suits in their own court." 23 Citizens from different states, foreign citizens, even the state's citizens cannot sue the state if it is based on federal laws. ${ }^{24}$ Furthermore, "states may 'consent' to suits that appear to be barred by the Amendment." 25

Looking to the Eleventh Amendment, it seems that states are granted immunity, however a different case for state officials. The Amendment does not make local government officials exempt from suits as ruled in Ex Parte v. Young, 209 US. 123(1908). In Central Virginia Community College v. Katz, 546 U.S. 356 (2006), the US Constitution's Bankruptcy Clause (Article 1 Section 8) revokes state sovereign immunity. In another case, Fitzpatrick v. Bitzer, 427 U.S. 445 (1976), congress can annul state sovereign immunity under the Eleventh Amendment concerning the enforcement of the Fourteenth Amendment. Over the years, the Eleventh Amendment has been questioned in cases; in brief, states do entitle sovereign immunity, but states may consent; government officials are not immune from suits, and in certain types of cases, the state can be sued.

In coastal management cases, as described by Sommerville, courts in California cannot avoid examining a battered distinction between "a liability producing ministerial function and immune discretionary function?" Factors that might influence decisionsare

17 Borchard, E.M. (1924). Government Liability in Tort. The Yale Law Journal, 34(1), 4. DOI:10.2307/788496.

18 Ibid, p. 4-5.

19 Ibid, p. 10.

20 Ibid, p. 13.

21 Clark, R.B., \& Jackson, V.C. (n.d.). The Eleventh Amendment. Retrieved from The Eleventh Amendment:https://constitutioncenter.org/interactive-constitution/interpretation/ amendmentxi/interps/133\#: :text=Georgia $\% 20(1793) \% 2 \mathrm{C} \% 20$ Congress $\% 20$ and,or $\% 20$ by $\% 2$ 0Citizens \%20or\%20Subjects. Accessed on July 30, 2020.

22 Ibid.

23 Oyes. Alden v. Maine, Retrieved from Oyes.org: https://www.oyez.org/cases/1998/98-436. Accessed May 17, 2021.

24 Clark, R.B., \& Jackson, V.C. (n.d.)., Op. Cit.

25 Ibid. 
"the importance to the public of the function involved, the extent to which liability would hamper the free exercise of the government missions, and the availability of other remedies. 26

Furthermore, on the issue of sovereign immunity, Sommerville argues that the California courts may discover the possibility of lengthening the government liability. ${ }^{27}$ "Sovereign immunity is intended to promote the public interest; suits in tort are initiated to provide a mechanism to distribute individual loss. It is logical to conclude that if more social utilitv is achieved with governmental liability, the courts may try to interpret the pertinent law to provide this result." 28

In brief, to determine whether such immunity exists: courts may consider public function, whether liability hinders discretionary to perform government missions and the existence of reliefs. Next, expanding government liability led to more benefits to the public. With those said above, whether discretion is always a shield for government tort liability, courts may look to the existence of mandatory duty to protect from injury. ${ }^{29}$

\subsection{The Indonesia's Legal Framework on Government Liability and Immunity Tort}

In comparison, rooted from the continental legal system, the source of law for government tort liability is Article 1365 of the Indonesia Civil Code, a code that was promogulated in the $19^{\text {th }}$ century by the Dutch. The article stipulates, "(e)very act of violating the law, which brings harm to other people, obliges the perpetrator who due to his wrongdoing to cause loss, to compensate the loss."

Originally, an action is interpreted as nonfeance (did not perform duties) or misfeance (wrongfully performed duties or rights) or malfeance (performed unauthorizedactions). ${ }^{30}$ The object of violation has been interpreted broader than just written laws (state laws and regulations). It was first started in 1919 by the Hoge Raad der Nederlander (Supreme Court of the Netherlands); ${ }^{31}$ in its decision dated January 31 to Lindenbaum v. Cohen, the court rules violation of other people's rights derived from the law may also be categorized as a tort. Afterwards, the interpretation has included violation of social norms, such as appropriateness, decency, and public interest. Hence, the article signifies five tort elements: action, violation of the law, fault, loss, and causality between the act and the loss.

Article 1365 Civil Codedoes not mention a literal subject of the action. However, we can use the governance on the subject of laws in civil matters - which are an individual and

26 Mary M. Sommervile, (1978). Government Tort Liability, The Urban Lawyer, 10(3), 392, Retrieved from https://www.jstor.org/stable/27890830

27 Ibid.

28 Ibid.

29 Ibid, p. 393-394.

30 Fuady, M. (2014). Perbuatan Melawan Hukum Pendekatan Kontemporer, Cetakan keempat. Bandung: PT Citra Aditya Bakti. pp 2-3. As cited by Yessica, E. (2014). Karakteristik dan Kaitan antara Perbuatan Melawan Hukum dan Wanprestasi. Jurnal Repertorium, 1(2), 53. Retrieved from https://media.neliti.com/media/publications/213011-karakteristik-dan-kaitan-antaraperbuata.pdf.

31 https://www.hogeraad.nl/english/ 
legal entity. The government is categorized as a public legal entity. Historically, theHoge Raad der Nederlanden rendered a decision in Ostermann case where the plaintiff asked for relief due to a governmental institution's action did not issue export permission. The lawsuit was dismissed in the first and appeal instances, but it was then examined by the Supreme Court. Judges granted to the plaintiff, reasoning regardless of the area of government's action, whether public or private field, the action violated laws. ${ }^{32}$

Meanwhile, different from common law countries above, government liability and impunity in tort have not been a continuous legal discourse. Referring to the Hoge Raad decision in Ostermann, a government institution can be sued for tort. Thus, Article 27 (2) of Law Number 2 of 2020, which stipulates that the government cannot be used for their actions in implementing the Law, is unusual. In an unprecedented situation, every government's decisions cause a higher risk of failure; it seems that the government tries to protect itself from lawsuits. Nevertheless, stipulating an immunity to lawsuits is useless as Indonesia's legal framework equips citizens with the right to sue and procedure to exercise the rights.

The 1945 Constitution of the Republic of Indonesia (Indonesian Constitution) guarantees human rights, from derogable and non-derogable rights. From right to life, living in a healthy environment, education, and social welfare, the Constitution is praised for its details on governing human rights. Those rights may be used as standing in suing government tort. Court Decision Number 118/Pdt.G.LH/ 2016/PN.Plk by the District Court of Palangkaraya can be used as an example. The plaintiffs used several articles of the Constitution as basis to sue the government for mishandling the fire crisis. First is Article 28 D (1) "Everyone has the right to recognition, guarantee, protection and fair legal certainty as well as equal recognition before the law." Second is Article $28 \mathrm{H}(1)$, states that "Every person has the right to live in physical and spiritual prosperity, residing and to a good and healthy living environment and has the right to obtain health services." To argue that the government had the duty to protect the right, the plaintiffs employed Article 28 I (4) "Protection, advancement, enforcement and fulfilment of human rights humans are the responsibility of the state, especially the government." It was then supported by specific laws regarding the case, Law Number 39 of 1999 concerning Human Rights Human and Law Number 32 of 2009 on Protection and Management of Environment.

Next, pursuant to Indonesian Constitution of 1945, there are four courtpillars. One is the general court, which has the competence to preside civil and criminal cases. A government agency/ official may be sued for government tort under Article 1365 Civil Code in the general court. Meanwhile, when it comes to lawsuit claims against a government agency/ official, the state administrative court has also competence. Law Number 51 of 2009 on State Administrative Court authorizes the court to adjudicate challenges to government agencies/ officials' decree.

32 Prodjodikoro, W. (2000). Perbuatan Melanggar Hukum: Dipandang dari Sudut Hukum Perdata. Bandung: CV. Mandar Maju. pp 84-85. As cited by Susilo, A.B. (2013). Reformulasi Perbuatan Melanggar Hukum oleh Badan atau Pejabat Pemerintahan dalam Konteks Kompetensi Absolut Peradilan Tata Usaha Negara. Jurnal Hukum dan Peradilan, 2(2), 295. doi: http://dx.doi.org/10.25216/jhp.2.2.2013.291-308. 
The law defines a state administrative decree as a stipulation written issue issued by a governance body or official state enterprises containing administrative legal actions based on the applicable laws and regulations, which are concrete, individual, and final, with legal consequences for a person or a civil legal entity. The phrase "concrete, individual, and final" can be described as follows: concrete means an object which was decided not abstract, however tangible, certain implies [the objective] can bedetermined, while individual means addressed to a certain target, and if the target is more than one people, then each person's name affected by the stated decision), and final (have been definitive, so already had legal consequences). ${ }^{33}$ The phrase clarifies a decree is not a regulation that contains abstract norms to general people, whereas regulation isan object of judicial review, not a lawsuit claim.

The state administrative court examines whether a plaintiff claims that a government decree violates Asas-Asas Umum Pemerintahan yang Baik (AAUPBgood governance principles) or not. ${ }^{34}$ Therefore, the writer can conclude although the opponent is the same (government), there is quite a distinction between government tort under the general court competence and administrative disputes over government decrees under the state administrative court. The opponent subject is the same, but the object and causes are different.Moreover, those two courts conduct different types of procedural law. Civil cases submitted to the general court are adjudicated using the Procedural Code (Herzien Inlandsch Reglement/Rechtreglement voor de Buitengewesten - HIR/RBG) governances. It stipulates documentary evidence, witness testimony, confession, oath, and inferences. 35 Other articles signify on-site examination and expert testimony as two other types of evidence. Specifically, civil procedure adheres asas hakim pasif (passivity of judge principle) where judges seek the formality of truth instead of material truth (bevond a reasonable doubt) - showing that judges rely on the fulfilment of evidence and be bound by the strength of evidence.

In tort cases, presiding judges focus on examining whether there is a causality relation between the actions performed by government agencies/ officials to the loss that the plaintiff suffered. The loss may include material and immaterial. If it is proven, the court mav punish the defendant for compensating or ordering certain actions to recover the plaintiff's loss.

According to Law Number 51 of 2009 on the Second Amendment of the Law Number 5 of 1986 on State Administrative Court, there are five types of evidence: documentary evidence, expert testimony, witness testimony, confession, and judges' inferences. The state administrative court uses the limited proof system (Domistus Litis). This system requires judges to be active to find material truth. ${ }^{36}$ Judges preside administrative cases

33 Herman, H. \& Noor, H.J. (2017). Doktrin Tindakan Hukum Administrasi Negara Membuat Keputusan (Beshikking). Jurnal Komunikasi Hukum, 2 (1), 82-95. doi: http://dx.doi.org/10.23887/ikh.v3i1.9240.

34 Putra, I.G.E, AAUPB Sebagai Dasar Pengujian dan Alasan Menggugat Keputusan Tata Usaha Negara. $\quad$ Retrieved from: ptun-palembang.go.id. http://www.ptunpalembang.go.id/upload_data/AAUPB.pdf. Accessed May 17, 2021.

35 Article $164 \mathrm{HIR}$.

36 Permata, T.C. as cited by Aji, A.Y., \& Laba, I.N. (2018). Kajian Hukum Sistem Pembuktian dalam Peradilan Tata Usaha Negara. Jurnal Lingkungan dan Pembangunan, 2(2), 27-42. Retrieved from https://www.ejournal.warmadewa.ac.id/index.php/wicaksana/article/ view/962. 
as stipulated in Article 107 of the Law, determine what must be proven, the burden of proof and judgment of proof, and the validity of proof, at least two pieces of evidence are needed based on the iudges' conviction. If a claim is proven, judges may declare government agencies/ officials' decrees as null and void.

Plaintiffs may also seek compensation and rehabilitation. In details, those stipulated by the Government Regulation Number 43 of 1991 concerning Compensation and Procedures for the Implementation of the State Administrative Court, the amount of compensation that the plaintiff can obtain is at least Rp. 250,000, - (two hundredandfifty thousand rupiah), and a maximum of Rp. 5,000,000, - (five million rupiah), taking into account the situation. The compensation that has been stipulated in the State Administrative Court's decision the amount is fixed and does not change even if there is a grace period between the date of the stipulation of said decision with the time payment of compensation.

The Law Number 30 of 2014 concerning Government Administration in Article 1 of general provisions defines a government administration decree as a written decision issued by government agencies/ officials in the administration of government. Furthermore, it introduced government administration action as an action performed by government agencies/ officials to carry out and/ or not take concrete actions in administering the government. It then adds legalitv and protection to human rights principles aside from the good government principles.

The governance by the Government Administration Law, as a result, created confusion about which court has the competence over the government's tort. Indonesia National Legal Development Bureau (BPHN), for one, notes that government tort cases adjudication would be more focused on handled by the administrative court - citing that Article 1365 of the Indonesian Civil Code governs a general provision on tort. ${ }^{37}$ The argument is valid if we only rely on stipulation under the State Administrative Law, but if we consider plaintiffs' objectives when submitting a claim against government agencies/ officials, the two possibilities are available.

Typically, if a claim's object is an action performed by government agencies/ officials' action, and a plaintiff intends to ask for material compensation, they will submitthecase to the general court. The state administrative court is addressed if the intention is toturn down a decree as it has a very specific arrangement on the maximum of material compensation. Take, for an example, in the case Front Pekerja Lokalisasi (FPL) and Komunitas Independen (KOPI) against Surabaya City Government, the DistrictCourt of Surabaya dismissed the claim, for one, reasoning that the claim related to a conflict regarding the government's policy thus falls under the state administrative court. 38

In another situation, litigants may try their cases in both courts. For example, in the case PT Putri Mahakam Lestari (PML) against Balai Pengelola Transportasi Darat WilayahII Sumatra Utara Province. The plaintiff won the case before the State Administrative

37 BPHN. (n.d.). Perbuatan Melawan Hukum oleh Penguasa di Era Otonomi Daerah. Retrieved from BPHN: https://bphn.go.id/data/documents/perbuatan_melawan_hukum_oleh_penguasa_ dalam_era_otonomi_daerah.pdf.Accessed May 18, 2021.

38 Faizal, A. (2018, September 3). Gugatan "Class Action" Warga Eks Dolly Ditolak di PN Surabaya. Retrieved from kompas.com: https://regional.kompas.com/read/2018/09/03/13555051/ gugatan-class-action-warga-eks-dolly-ditolak-pn-surabaya. Accessed on April 9, 2021. 
Court of Medan. The court punished the defendant for issuing a decree and/oractasked in the claim - declaring that the plaintiff is the winner of a construction project through official online bidding. Later, the defendant did not perform accordingly to the state administrative court's ruling; the plaintiff then submitted a government tort claim tothe general court of Medan. The plaintiff asked the court to declare that the defendant commits tort and shall pay material compensation for about 37 billion rupiahs and immaterial compensation for 1 billion rupiahs. ${ }^{39}$ Referring to PML's case above, itisclear to differentiate obiectives suing government agencies/ officials for tort in the general court or an administrative claim to the state administrative court.

The confusion of which court has the competence over government tort began to sort out in 2019 as the Supreme Court enacted Supreme Court Regulation Number 2 of 2019 regarding Guidance on Dispute Settlement of Government Action and Court Competence to Adjudicate Tort Committed by Government Agency/ Official (Onrechtmatige Overheidsdaad). The table 1 shows several legal definitions from Article1 of the Regulation.

\begin{tabular}{|l|l|}
\hline Government action & $\begin{array}{l}\text { Anv actions committed by government agencv or official to } \\
\text { do or not to do concrete action in performing governance. }\end{array}$ \\
\hline $\begin{array}{l}\text { Government action } \\
\text { dispute }\end{array}$ & $\begin{array}{l}\text { Any disputes arisen in the field of government administration } \\
\text { between citizen and government agency or official as a result } \\
\text { from government action. }\end{array}$ \\
\hline Government tort & $\begin{array}{l}\text { Any disputes that carry claim to declare invalidity or to } \\
\text { nullify any government action or to abort binding force along } \\
\text { with compensation claim pursuant to the relevant law and } \\
\text { regulations. }\end{array}$ \\
\hline
\end{tabular}

Table 1. Definition of government action, government action dispute, and government tort from Supreme Court Regulation Number 2 of 2019 regarding Guidance on Dispute Settlement of Government Action and Court Competence to Adjudicate Tort Committed by Government Agency/ Official

Referring to the government tort definition above, citizens who act as the plaintiff must go against government agency/ official before a state administrative court. It is then supported by Article 2 of the regulation states that a government tort case is the competence of a state administrative court. According to Article11, the Supreme Court orders district courts that currently are examining government tort cases must declare they do not have authority over the cases. Unlike the PML's case, with these governances, two submissions addressed to two different courts, government tort caused by government action must be submitted to the state administrative court.

\subsection{The Comparison of Practices in Examining Government Tort by DistrictandState Administrative Courts}

39 Putusan PTUN Tidak Dijalankan PT PML Ajukan Gugatan PMK ke PN Medan. (n.d.). Retrieved from Waspada.co: https://waspada.co.id/2020/08/putusan-ptun-tidak-dijalankan-pt-pmlajukan-gugatan-pmh-ke-pn-medan/. Accessed on October 11, 2020. 
Unlike other common law countries that develop their interpretation of government immunity, Indonesia is not equipped with that. Nevertheless, to have an understanding of this issue, several cases of government tort might give a bit of view. First, in a citizen lawsuit claim against the Governor of DKI Jakarta, with Court Decision Number 53/PDT.G/2012/PN.JKT.PST, the General Court of Central Jakarta ruled that the government has done proper dan responsible performance to solve traffic congestion, let alone the fact the residents do not yet receive the result.

Second, Court Decision Number 118/Pdt.G.LH/ 2016/PN.Plk is a result of a citizen lawsuit brought by residents of Kalimantan to the District Court of Palangkaraya against the President, Minister of Environment and Forestry, Minister of Agriculture, Minister of Agrarian Affairs and Spatial Planning/ Head of Bureau of Land Management, Minister of Health, Governor of Central Kalimantan, Local Parliament of Central Kalimantan, the presiding judges ruled in favour to the plaintiffs. Upon the trial examination, it is found that the defendants have failed in handling a massive fire crisis in Kalimantan.

The plaintiffs reasoned that the defendant is committing tort: violating duties as stipulated in Article $28 \mathrm{H}$ of the Indonesian Constitution, Article 2 and 9 paragraph 3 Law Number 39 of 1999 concerning Human Rights and Article 65 paragraph 1 Law Number 39 of 2009 regarding Environmental Protection and Management. ${ }^{40}$ Due tothe mishandling, the fire crisis affected other neighbouring countries, death tolls; residents suffered respiratory infections and disruption to community activities.

The object of the suit is the defendants' actions. Unlike a typical government tort claim, as this is a citizen lawsuit claim, there was no monetary relief. In the claim, the plaintiffs requested the court declare that the defendants committed a tort and punish them for performing environmental relief actions to the fire area, establish a joint task force and national and local regulations to implement the actions and pay for the trial cost. ${ }^{41}$ The President's defence includes sufficient regulations and instructions that have been mandated to his ministers in handling the crisis. ${ }^{42}$ The other defendants also submitted similar defences. There is no such immunity defence used in it. Aside from a documentary shred of evidence, the presiding judges examined witness and expert testimonies. A resident in the fire crisis area testified for the plaintiffs' side, explaining the loss the residents suffered due to the fire crisis before the court. ${ }^{33} \mathrm{He}$ mentioned how he tried to express his concern about the fire crisis to the local parliament. On the defendants' side, a resident testified that the government had performed adequately, showing that this agency responded when he contacted the Ministry of Environment and Forestry. 44

An expert from the plaintiffs focused on the human rights approach, stating that the government must restore the environment if such destruction occurred. ${ }^{45}$ Meanwhile, an expert from the defendants claimed that the peatlands' destruction could cause fire

\footnotetext{
40 Court Decision Number 118/Pdt.G.LH/ 2016/PN.Plk, pp 6-7.

41 Court Decision Number 118/Pdt.G.LH/ 2016/PN.Plk, pp 32-35.

42 Court Decision Number 118/Pdt.G.LH/ 2016/PN.Plk, pp 42.

43 Court Decision Number 118/Pdt.G.LH/ 2016/PN.Plk, pp 124-132.

44 Court Decision Number 118/Pdt.G.LH/ 2016/PN.Plk, pp 149.

45 Court Decision Number 118/Pdt.G.LH/ 2016/PN.Plk, pp 133-138.
} 
crises-created hotspots. ${ }^{46}$ The expert noted that the Ministry of Environment and Forest had performed its duties, but because of the lack of staff, it could not treat all hotspots ${ }^{47}$. Saying so, the expert asserted that fire crises must be a shared responsibility, other institutions must perform too. ${ }^{48}$ Another expert from the defendants described the separation of power arrangement in Indonesia, continued by an explanation that the parliaments cannot be held accountable for tort. ${ }^{49}$

In a chronologicall order, the presiding judges, in their consideration, wrote that: the lawsuit fulfilled formality requirements and laid out clear facts and reasons to sue. Next, the judges used the Supreme Court Chief Decree Number 36/KMA/SK/II/2013 concerning Guidance on Handling Environmental Cases. 50 According to the iudges, the local parliament may be interpreted as a state institution in environmental cases. ${ }^{51}$

In determining fault, the judges cited environmental protection principles in liability. In civil cases, liability based on fault and strict liability are used. Liability based on fault is governed by Article 1365 of the Indonesian Civil Code. As strict liability is used under the Law on Environmental Protection and Management. Under strict liability, the element of fault does not need to be proven by the plaintiffs to claim compensation instead, the defendants bear the responsibility to prove that they did not commit the tort. In the case $a$ quo, the judges examine facts with evidence provided to check violation Article 1365 of the Indonesian Civil Code and the Law on Environmental Protectionand Management. The judges also cited that the fire crisis happened repeatedly and caused damages suffered by the residents and destruction of the environment. ${ }^{52}$ In conclusion, the defendants are declared committing a tort. The judges then ordered each of the defendants to perform certain actions to restore the environment, establish regulations, perform public transparency to publish destructed lands and companies responsiblefor the grounds, and create a task force. ${ }^{53}$ Responding to this district court decision, on behalf of the government, the Ministry of Environment and Forestry appealed to the Higher Court of Central Kalimantan. With Court Decision Number 36/Pdt/2017/PT PLK, the Court denied the appeal. The defendants then tried their last resort by submitting a final appeal to the Supreme Court. The final appeal was denied by Court Decision Number 3555 K/Pdt/2019. Consequently, the verdict by the District Court of Palangkaraya stands.

With the new Supreme Court regulation, noting that many cases of government tort already logged in the general court, at the same time, the state administrative court is given the sole competence to examine government tort claims. Before the State Administrative Court of Japrovincial state a dministrative court, one of the notable cases has received its result. They were exercising their rights, Jakarta residents who suffered from a flood at the beginning of 2020. Through a class-action submission, a group of 312 (three hundred and twelve) plaintiffs argued that the Governor of Jakarta failed to perform adequately to respond to the flood. It is recorded that 67 (sixty-seven) residents

46 Court Decision Number 118/Pdt.G.LH/ 2016/PN.Plk, pp 140.

47 Court Decision Number 118/Pdt.G.LH/ 2016/PN.Plk, pp 145-146.

${ }^{48}$ Court Decision Number 118/Pdt.G.LH/ 2016/PN.Plk, pp 145.

${ }^{49}$ Court Decision Number 118/Pdt.G.LH/ 2016/PN.Plk, pp 155.

50 Court Decision Number 118/Pdt.G.LH/ 2016/PN.Plk, pp 162.

51 Court Decision Number 118/Pdt.G.LH/ 2016/PN.Plk, pp 162.

52 Court Decision Number 118/Pdt.G.LH/ 2016/PN.Plk, pp 171-183.

53 Court Decision Number 118/Pdt.G.LH/ 2016/PN.Plk, pp 191-194. 
had died, ${ }^{54}$ and electricity shut down, disturbing residents' activities. ${ }^{55}$ The plaintiffs asked for material and immaterial compensations to the Central District Court of Jakarta. Eight months after submission, in January 2021, the Central District Court of Jakarta's presiding judges declared the lawsuit's inadmissibility stating the case is not under its competence citing the Supreme Court Regulation. It seems that the presiding judges of the case were unsure whether to proceed with the case or not. Before declaring the inadmissibility, the judges presided over the case through preliminary examination to determine class action terms fulfilment. Facts and claims from both sides were then presented before the court, along with a rebuttal session. When it was about to enter the evidentiary process, the case that registered under number 27/Pdt.G/2020/PN Jkt.Pst rendered as dismissed reasoning that examining government tort is no longer the general court's competence; the claim must be submitted to a state administrative court. 56

Although pursuant to HIR/RBG, courts may declare claims as inadmissible at any time during the trial; typically, it was declared since the beginning. It is taking into the fact that the Supreme Court Regulation Number 2 Year 2019 came into force in August2019. This recent development would certainly affect the ongoing Covid-19 lawsuits before district courts. Many predict it would end with the same fate as the Jakarta flood case.

The Supreme Court Regulation must be regarded as a clear intention to end court competence's status quo in examining government tort cases. There seems a reluctance by district court judges to dismiss government tort cases. On the opposite, state administrative court judges are unsure of examining government tort cases. One example is case number $161 / \mathrm{G} / \mathrm{TF} / 2020 /$ PTUN.JKT submitted to the Jakarta State Administrative Court.

The case's object is the Education Division, and the Governor of Jakarta's concreteaction that implements an age requirement for school admission instead of academic qualification and multiplication of applicants' average score performance with their schools' accreditation. The plaintiffs consisted of Parents Association 8113, and individual parents claimed that the concrete action resulted into a rejection of many children from public school admission. The plaintiffs tied their claims with legal reasoning pursuant to laws regarding state administrative court and government regulation. The objects of the case changed during the trial to connect it with the Supreme Court regulation. The objects of the case changed into the defendant actionfor not providing alternative choices for applicants that did not get successfully accepted in the public-school admission and for not giving a solution for them in such a situation.

54 Fadhil, H. (2020, January 6). Korban Meninggal Banjir Jakarta-Jabar-Banten Bertambah Jadi 67 Orang. Retrieved from Detik.com: https://news.detik.com/berita/d-4848681/korbanmeninggal-banjir-jakarta-jabar-banten-berta mbah-jadi-67-orang. Accessed on April 9, 2021.

55 Rosana, F.C. (2020, January 1). Jakarta Flooding; PLN Turns Off Electricity in 700 areas. Retrieved from Tempo.co: https://en.tempo.co/read/1289981/jakarta-flooding-pln-turns-offelectricity-in-700-areas. Accessed on April 9, 2021.

56 Wijaya, L.D. (2021, January 13). Sidang Gugatan Banjir Jakarta, Hakim Terima Eksepsi Anies Baswedan, Retrieved from Tempo.co: https://metro.tempo.co/read/1422637/sidanggugatan-banjir-jakarta-hakim-terima-eksepsi-anies-baswedan/full\&view=ok. Accessed on April 1, 2021. Until February 10, 2020, the Central District Court of Jakarta has not yet published the court decision on the Supreme Court's website (SIPP). 
The presiding judges stated that the court must examine first whether the concreteaction element is fulfilled. Next is to determine the validity of whether such concrete action may be declared as tort, at least by examine three considerations:

1. There any law that requires the government to do or to omit a certain action

2. There any loss suffered by the plaintiffs due to omission to the obligation to perform not to perform a certain action;

3. In performing such concrete action, is there any procedural or material components of the action violating the AAUPB

On the merit of the case, the presiding judges ruled that the object is not concrete. Furthermore, the decree that enabled the defendants to conduct the school admission that is the Decree of the Head of Education Office of Jakarta Province Number 501 of 2020 regarding Technical Guidance on Student Admission Academic Year of 2020/2021 is found has no room for the defendants to perform differently from what it is mandated. Then further explaining that the decree must be implemented as it is, no alternative interpretation would open a room for misconduct, corruption, collusion, and nepotism - becoming a contra-productive tool. In the decision, the judges reasoned that the Decree's variation of school admissions must be acknowledged as alternativechoices itself. The judges also reasoned instead of claiming for government tort, the plaintiff must address the decree's validity; thus, it will be the Supreme Court's competence in hearing a judicial review of the decree. As a result, the judges declared a dismissal of the claim.

Looking at how the judges reasoning in the decision, the writer believes that it shows how there is the inconsistency of judges' interpretation on the concrete action. Thereare two decisions to compare, both were decided by the State Administrative Court of Jakarta; first is Decision Number 99/G/2020/PTUN-JKT in the case of Semanggi I, Semanggi II, and Trisaksi tragedies' ongoing investigation; another is Decision Number: 230/G/TF/2019/PTUN-JKT in the case regarding internet shutdown in Papua. Both cases were submitted to Jakarta's state administrative court, the one who dismissed the public-school admission government tort above. In Court Decision Number 99/G/2020/PTUN-JKT, plaintiffs are the family members of victims of those tragedies. They sued the Jaksa Agung (Prosecutor General) for his statement before a prosecutorial office and parliament meeting. On a meeting with the House of Representatives (DPR), his statement, in general, stated the tragedies were not qualified as gross violation of human rights. Hence, he asserted that the Komisi Nasional Hak Asasi Manusia (Indonesia National Human Rights Commission) should not continue the investigation; hence there is no reason to establish an ad hoc human rights court. ${ }^{57}$

The plaintiffs claimed that the statement has made the plaintiffs suffered, theyhavebeen advocating the cases for years, but as the cases are tied with politics, the cases have been put on hold. Additionally, they noted that the defendant had undermined the commission's investigation efforts, along it has caused uncertainty in law enforcement.

57 Nugraheny, D.E. (2020, January 01). Pernyataan Jasa Agung dan Rekomendasi DPR 2001 tentang Tragedi Semanggi. Retrieved from Kompas.com: https://nasional.kompas.com/read/2020/01/20/11323651/pernyataan-jaksa-agung-danrekomendasi-dpr-2001-tentang-tragedi-semanggi?page=all. Accessed May 17, 2021. 
In the future, the statement might influence the prosecutorial office's decision not to continue the cases to prosecution. 58

The presiding judges ruled that the defendant is found liable for a government tort. Written in the decision, the judges examined the qualification of a government tort from facts provided by the parties. Referring to the laws regarding administrative governance, the defendant must be a government agency or official. The judges qualified the defendant as it is. The statement is categorized as concrete action. Unlike the judges in the public school's admission case, the judges in this case focused on the action itself: giving statement. In the public school's admission case, the plaintiffs at first pointed out the defendants' action conducting the admission but then through the course of trials, the plaintiffs changed the object of the case to turn it to action for not performing. In qualifying, the defendant's action giving the statement as tort, the presiding judges in the Semanggi I, Semanggi II, and Trisakti case connected it with violation of AAUPB: precision and truthfulness. There is no need to turn the object of the case to an actionfor not performing precision and truthfulness as the action giving statement is the object of the case. 59

In the case of the internet shutdown, with Court Decision Number: 230/G/TF/2019/PTUN-JKT the presiding judges of State Administrative Court of Jakarta did the same test. The defendants: the Minister of Communication and Information and President, are qualified as the government in a tort case. Further, the presiding judges examined the decision to shut down the internet as an action that violating AAUPB and causing the loss of plaintiffs' civil and political rights, especially rights to speech and democracy.

With that being elaborated, it is a progress that no more confusion for justice seekers to where government tort claims must be filled: to the state administrative court. Further, in the issue of immunity and liability, cases elaborated above both in the past decided by the general court and after 2019 by the state administrative courts show that the government can be sued because citizens have their basis which is their rights to do so, along with specific rights that guaranteed by the constitution and laws. In the land of Indonesia, the government is not only bound by laws and regulations on the limit of their authority but also to perform accordingly to AAUPB. Nevertheless, it is found that the problem is in the inconsistency of judges to determine concrete action in deciding merit of government tort.

\subsection{Covid-19 Tort Claim Against the Government, What Judges May Pay Attention To}

Using media coverage, it is found that at least there are two class-action lawsuits were submitted regarding the performance of government agencies/ officials in handling Covid-19 pandemic. The first was filled in April 01, 2020, to the General Court of Central Jakarta. The plaintiffs consist of six citizens who went against Joko Widodo as the President of Indonesia.

\footnotetext{
58 Court Decision Number 99/G/2020/PTUN-JKT, pp 6-7.

59 Court Decision Number 99/G/2020/PTUN-JKT, pp 91-115.
} 
The plaintiffs cite two and half months after Wuhan; the government did not act promptly even gave statements that underestimated the pandemic scale. They also recalled a number of ministers who made jokes about people concern over the pandemic management, such as stating that the coronavirus would not affect Indonesia because Indonesians love to eat nasi kucing (local dish), the virus would be declined to enter the country because its convoluted bureaucracy. Further, the plaintiffs argue the uncertain policies, whether quarantine or large-scale of social distancing, created confusion, later caused economic uncertainty. 60

The case is registered with the number 186/Pdt.G/2020/PN JKT.Pst. The plaintiffs request to the court to declare the defendant acting as the President of Indonesia neglected his duty and function to anticipate and handling Covid-19 pandemic, to punish the defendant compensating the plaintiffs for their loss caused by his negligent for about ten billion and twelve million rupiahs (twelve million for the material loss and ten billion for the immaterial loss shown by anxiety and insecurity suffered by the plaintiffs), to punish the defendant paying the trial cost, and to punish the defendantby declaring an immediate verdict even if there is verzet challenge, appeal, or final appeal.

Recorded by the court's official website, the most recent hearing of the case was held on Wednesday 08, 2020, where judges rendered a decree on the fulfilment of formalityclass action requirements. The presiding judges had listened to the claim, defence, and rebuttal from both parties. Until October 11, 2020, there is no further hearings information updated on the website.

The second case was filled to the General court of Pematangsiantar, brought by eleven residents of Gang Demak, Kelurahan Matoba, Kecamatan Siantar Utara, Kota Pematangsiantar against the Mayor of Pematangsiantar. Unlike the previous case, the subject of the Pematangsiantar case is a local government, and the object is the Major announcing that the residents' neighbourhood infected by Covid-19. It is found that the local government misidentified a resident who was once declared as a suspect of Covid19. Local small and medium sellers in the area had suffered decreasing in sales caused by the announcement. The plaintiffs ask for material compensation (118 million rupiahs), immaterial relief (11 billion), and vindication. ${ }^{61}$

If we put aside the possible outcomes of those cases, this paper will analyze the case's nature from the plaintiff's requests and connect it with the previous section's findingsto look ahead to what judges may consider in examining this type of case. Both are government tort cases because the subjects are government agencies or officials. The object of those cases is government agencies or officials' actions. Both cases explain how the governments' actions caused their material and immaterial sufferings on the issueof causality. The case would likely be dismissed as it happened to the Jakarta flooding case. The presiding judges would likely declare that it has no longer the competence over the government tort and advise the plaintiffs to file before the state administrative court. If

60 Briantika, A. (2020, April 3). Gugatan Warga ke Presiden Jokowi Sebab Lamban Antisipasi Covid19. Retrieved from Tirto.id: https://tirto.id/gugatan-warga-ke-presiden-jokowi-sebablamban-antisipasi-covid-19-eKCT. Accessed on October 11, 2020.

61 Pribadi, T. (2020, July 2). Warga Korban Covid-19 Gugat Walikota Pematangsiantar. Retrieved from Kompas.com: https://regional.kompas.com/read/2020/07/02/21470501/wargakorban-covid-19-gugat-wali-kota-pematangsiantar?page=all. Accessed on October 11, 2020. 
the general court rejects it, what will be the chance before the state administrative court. Next, regarding the formality requirements, the question is would the courts accept to examine the cases despite the existence of Article 27 (2) Law Number 2 of 2020 concerning the Stipulation of Government Regulation in Lieu of Law Number 1 of 2020 concerning State Financial Policy and Financial System Stability for HandlingtheCorona Virus Disease 2019 (Covid-19) Pandemic and/or in the Context of Facing Threats That Endanger the National Economy and/or Financial System Stability Into Lawwhich states that the government's institutions by this law cannot be sued in civil and criminal cases if maintaining good faith in their performance. In contrast, from all cases discussed above, citizens have the right to sue the government.

The next question is how to examine the case. As this is public health management cases, the source may include the Indonesian Constitution, Article 1365 of the Indonesian Civil Code, Law Number 24 of 2007 on Disaster Management, Law Number 6 of 2018 on Health Quarantine, the 2005 International Health Regulation. Article 28 H (1) of the Indonesian Constitutionstates that "Everyone has the right to live in physical and spiritual prosperity, to have a place to live, and to have a good and healthy living environment and the right to obtain health services."

The Law on Disaster Management includes pandemic as a non-natural disaster. As a matter of fact, the Law governs that the government and local governments areincharge of disaster management. As for responsibility, government responsibility in the implementation disaster management includes:

a. disaster risk reduction and reduction integration disaster risk with development programs;

b. protection of the community from disaster impacts;

c. guarantee the fulfilment of the rights of the people and refugees affected by the disaster fairly and accordingly to the minum service standards;

d. recovery from disaster impacts;

e. allocation of internal disaster management budget by adequate state revenueand expenditure;

f. allocation of internal disaster management budget ready to use form of funds; and

g. maintenance of authentic and credible archives/ documents from the thread and impact of a disaster.

The Law on Health Quarantine governs that the implementation of health quarantine aims at to:

a. protect the community from disease and/or potential public health risk factors raises to a public health emergency;

b. prevent and ward off disease and/or factors potential of public health risks raises to a public health emergency;

c. increase national resilience in the field of public health; and

d. provide protetction and legal certainty for community and health workers.

In the issue of duties, the Law on Health Quarantine mandates that the central government and local goverments are responsible for protecting public health from disease and/or public health risk factors that can lead to a public health emergency. 
Additionally, Indonesia is a member of World Health Organization (WHO). The organization through its assembly enacted and revised a regulation, namely the 2005 International Health Regulation (IHR) which is a legally binding instrument to the 196 members of the WHO in the global health security issue. ${ }^{62}$ The IHR clearly mandates countries to act, but the IHR does not provide sanction for violation. Additionally, the WHO does not equip with a formal force and adjudication mechanism. ${ }^{63}$ Thus, it lies upon the members' good faith to comply. In the case of Indonesia, the country showed its commitment to the Regulation, for example by enacting the Health Quarantine Law and setting up its public health system with surveillance system. ${ }^{64}$, The question is how courts in Indonesia will use the IHR to examine cases regarding Covid-19. Using the IHR, courtsmay examine whether the government effectively employed surveillance systems and laboratories to detect potential health threats, and reported on the potential for a public health emergency." 65

With those being said, there are the basis to sue the government for Covid-19 management. To argue the government must perform well handling the pandemic are guaranteed by laws regarding disaster management and health quarantine above. Specifically, before a state administrative court, presiding judges must examine whether the government omission and late response to the pandemic as claimed by the plaintiff fulfils the concrete action elements and violating AAUPB.

\section{Conclusion}

By assessing the practice of courts examining government tort cases, it is found that the right to sue may be derived from rights guaranteed by the 1945 Constitution of the Republic of Indonesia. Article 1365 of the Indonesian Civil Code will be supported with more specific laws and regulations in special cases. In the case of Covid-19 management, laws regarding disaster and public health care management must also be examined. It is also important to note that judges may also look at the case's public interest impact in establishing fault, especially in class action cases. Indonesia's justice system, notably, does not develop immunity doctrine as the country rooted in the continental civil system, and in fact, laws and regulations and principles of law may be used to examine tort cases. With the enactment of the Supreme Court Regulation Number 2 of 2019, government tort is examined by looking to concrete actions elements and contrasting it using legislation and the AAUPB.

62 WHO. International Health Regulation. Retrieved from who.int: https://www.who.int/healthtopics/international-health-regulations\#tab=tab_1. Accessed May 17, 2021.

63 Nadilla, S. (2020). Krisis Covid-19: Perspektif Hukum Internasional Terhadap Pandemi. Majalah Hukum Nasional, 50 (2), 272. Retrieved from http://mhn.bphn.go.id/index.php/MHN/article/view/65.

64 PKSE Tanjung Pinang (2019, 23 April). Implementasi International Health Regulation (IHR) 2005 di Indonesia. Retrieved from ktptanjungpinang.com: https://kkptanjungpinang.com/implementasi-international-health-regulations-ihr-2005-diindonesia/. Accessed May 17, 2021).

65 Susanti, L. (2020, May 12). Taking Jokowi to Court Over Covid-19: Is the Government Liable? .Retrieved from Indonesia at Melbourne: https://indonesiaatmelbourne.unimelb.edu.au/taking-jokowi-to-court-over-covid-19-is-thegovernment-liable/. Accessed on October 11, 2020. 


\section{References}

\section{$\underline{\text { Books }}$}

Fuady, M. (2014). Perbuatan Melawan Hukum Pendekatan Kontemporer, Cetakan keempat.

Bandung: PT Citra Aditya Bakti.

\section{Journals}

Aji, A.Y., \& Laba, I.N. (2018). Kajian Hukum Sistem Pembuktian dalam Peradilan Tata Usaha Negara. Jurnal Lingkungan dan Pembangunan, 2(2). Retrieved from https://www.ejournal.warmadewa.ac.id/index.php/wicaksana/article/view/9 $\underline{62}$

Aronson, M. (2008). Government Liability in Negligence. Melbourne University Law Review, 32(1). Retrieved from https://law.unimelb.edu.au/_data/assets/pdf_file/0008/1705769/32_1_2.pdf

Borcard, E.M. (1924). Government Liability in Tort. The Yale Law Journal, 34(1). doi:10.2307/788496.

Herman, H. \& Noor, H.J. (2017). Doktrin Tindakan Hukum Administrasi Negara Membuat Keputusan (Beshikking). Jurnal Komunikasi Hukum, 2 (1). doi: http://dx.doi.org/10.23887/jkh.v3i1.9240.

Nadilla, S. (2020). Krisis Covid-19: Perspektif Hukum Internasional Terhadap Pandemi. Majalah Hukum Nasional, 50 (2), 272. Retrieved from http://mhn.bphn.go.id/index.php/MHN/article/view/65. doi: https://doi.org/10.33331/mhn.v50i2.65

Susilo, A.B. (2013). Reformulasi Perbuatan Melanggar Hukum oleh Badan atau Pejabat Pemerintahan dalam Konteks Kompetensi Absolut Peradilan Tata Usaha Negara. Jurnal Hukum dan Peradilan, 2(2). doi: http://dx.doi.org/10.25216/jhp.2.2.2013.291-308.

Rosenthal, L. (2007). A Theory of Government Damage Liability: Torts, Constitutional Torts, and Takings. University of Pennsylvania Journal of Constitutional Law, 9(3). Retrieved from https:// papers.ssrn.com/sol3/papers.cfm?abstract_id=978833.

Sommervile, Mary M. (1978). Government Tort Liability, The Urban Lawyer, 10(3), 392, Retrieved from https://www.jstor.org/stable/27890830

Yessica, E. (2014). Karakteristik dan Kaitan antara Perbuatan Melawan Hukum dan Wanprestasi. Jurnal Repertorium, 1(2). Retrieved from https://media.neliti.com/media/publications/213011-karakteristik-dan-kaitanantara-perbuata.pdf.

\section{Research report}

BPHN. (n.d.). Perbuatan Melawan Hukum oleh Penguasa di Era Otonomi Daerah. Retrieved from

https://bphn.go.id/data/documents/perbuatan_melawan_hukum_oleh_pengu asa_dalam_era_otonomi_daerah.pdf. Accessed May 18, 2021.

\section{Website}

Akhlas, A.W. (2020, June 25). Crisis Like No Other Will Shrink Indonesia Economy. Retrieved 
from

The

Jakarta

Post:

https://www.thejakartapost.com/news/2020/06/25/crisis-like-no-other-willshrink-indonesias-economy-imf-forecasts.html. Accessed on October 11, 2020.

Briantika, A. (2020, April 3). Gugatan Warga ke Presiden Jokowi Sebab Lamban Antisipasi Covid-19. Retrieved from Tirto.id: https://tirto.id/gugatan-warga-ke-presidenjokowi-sebab-lamban-antisipasi-covid-19-eKCT. Accessed on October 11, 2020.

Clark, R.B., \& Jackson, V.C. (n.d.). The Eleventh Amendment. Retrieved from TheEleventh Amendment: constitution/interpretation/amendmentxi/interps/133\#: :text=Georgia \% 20(1793)\%2C \% 20Congress $\% 20$ and,or $\% 20$ by $\% 2$ 0Citizens\%20or\%20Subjects. Accessed on July 30, 2020.

Fadhil, H. (2020, January 6). Korban Meninggal Banjir Jakarta-Jabar-Banten Bertambah Jadi 67 Orang. Retrieved from DetikNews: https://news.detik.com/berita/d4848681/korban-meninggal-banjir-jakarta-jabar-banten-bertambah-jadi-67-orang. Accesed on April 9, 2021

Faizal, A. (2018, September 3). Gugatan “Class Action" Warga Eks Dolly Ditolak di PN Surabaya. Retrieved from Kompas.com: https://regional.kompas.com/read/2018/09/03/13555051/gugatan-classaction-warga-eks-dolly-ditolak-pn-surabaya. Accesed on April 9, 2021

Garjito, D. (2020, March 4). Komunikasi Menkes Terawan Dikritik, 4 PernyataanSoal Corona Jadi Sorotan. Retrieved from suara.com: https://www.suara.com/news/2020/03/04/101853/komunikasi-menkesterawan-dikritik-4-pernyataan-soal-corona-jadi-sorotan. Accessed on April 03, 2020.

Karunia, A.M. (2020, April 14). Luhut: Pemerintah Akan Segera Tarik Turis dari China, Korsel, dan Jepang. Retrieved from Kompas.com: https://money.kompas.com/read/2020/04/14/211200226/luhut-pemerintahakan-segera-tarik-turis-dari-china-korsel-dan-jepang. Accessed on October 11, 2020

Nugraheny, D.E. (2020, January 01). Pernyataan Jasa Agung dan Rekomendasi DPR 2001 tentang Tragedi Semanggi. Retrieved from kompas.com: https://nasional.kompas.com/read/2020/01/20/11323651/pernyataan-jaksaagung-dan-rekomendasi-dpr-2001-tentang-tragedi-semanggi?page=all. Accessed May 17, 2021.

Oyes. Alden v. Maine, Retrieved from Oyes.org: https://www.oyez.org/cases/1998/98-436. Accessed May 17, 2021.

PKSE Tanjung Pinang (2019, 23 April). Implementasi International Health Regulation(IHR) 2005 di Indonesia. Retrieved from kktptanjungpinang.com: https://kkptanjungpinang.com/implementasi-international-health-regulationsihr-2005-di-indonesia/. Accessed May 17, 2021).

Pribadi, T. (2020, July 2). Warga Korban Covid-19 Gugat Walikota Pematangsiantar. Retrieved from Kompas.com: https://regional.kompas.com/read/2020/07/02/21470501/warga-korbancovid-19-gugat-wali-kota-pematangsiantar?page=all. Accessed on October 11, 2020.

Putri, Z. (2020, April 1). Pedagang UMKM Gugat Jokowi Rp 10 Miliar Buntut Penanganan 
Corona. Retrieved from Detik.com: https://news.detik.com/berita/d4961584/pedagang-umkm-gugat-jokowi-rp-10-miliar-buntut-penanganancorona. Accessed on April 03, 2020

Putusan PTUN Tidak Dijalankan PT PML Ajukan Gugatan PMK ke PN Medan. (n.d.). Retrieved from Waspada.co: https://waspada.co.id/2020/08/putusan-ptuntidak-dijalankan-pt-pml-ajukan-gugatan-pmh-ke-pn-medan/. Accessed on October 11, 2020.

Respons Istana atas Gugatan Warga ke Jokowi Soal Corona . (2020, A pril 3). Retrieved from CNN Indonesia: https:// www.cnnindonesia.com/nasional/20200403075252-32489858/respons-istana-atas-gugatan-warga-ke-jokowi-soal-corona. Accessed on April 03, 2020.

Reuters Staff. (2020, June 24). IMF Predicts Deeper Global Recession due to Coronavirus Pandemic. Retrieved from Reuters: https://www.reuters.com/article/us-healthcoronavirus-imf-outlook/imf-predicts-deeper-global-recession-due-tocoronavirus-pandemic-idUSKBN23V1X8. Accessed on October 11, 2020.

Rosana, F.C. (2020, January 1). Jakarta Flooding; PLN Turns OffElectricity in 700 areas. Retrieved from Tempo.co: https://en.tempo.co/read/1289981/jakarta-floodingpln-turns-off-electricity-in-700-areas. Accessed on April 9, 2021.

Saputra, D. (2021, March 19), Survei BI: 87,5 Persen UMKM Indonesia Terdampak Pandemi Covid-19. Retrieved from Bisnis.com: https://ekonomi.bisnis.com/read/20210319/9/1370022/survei-bi-875-persenumkm-indonesia-terdampak-pandemi-covid-19. Accessed on March 17, 2021.

Setiawan, S.R.D. (2020, April 17). Sebanyak 37.000 UMKM Terdampak Virus Corona. Retrieved from Kompas.com: https://money.kompas.com/read/2020/04/17/051200426/sebanyak-37.000umkm-terdampak-virus-corona. Accessed on October 11, 2020.

Susanti, L. (2020, May 12). Taking Jokowi to Court Over Covid-19: Is the Government Liable? .Retrieved from Indonesia at Melbourne: https://indonesiaatmelbourne.unimelb.edu.au/taking-jokowi-to-court-overcovid-19-is-the-government-liable/. Accessed on October 11, 2020.

Wijaya, L.D. (2021, January 13). Sidang Gugatan Banjir Jakarta, Hakim Terima Eksepsi Anies Baswedan. Retrieved from Tempo.co:

https://metro.tempo.co/read/1422637/sidang-gugatan-banjir-jakarta-hakimterima-eksepsi-anies-baswedan/full\&view=ok. Accessed on April 1, 2021.

WHO. International Health Regulation. Retrieved from who.int: https://www.who.int/health-topics/international-healthregulations\#tab=tab_1. Accessed May 17, 2021.

WHO. Retrieved from who.intl: https:// covid19. who.int/?gclid=CjwKCAjwqIiFBhAHEiw ANg9sznOyLBuTXz9 p30IQMA4Eo85Xqx16Pb8EbQwLvb1kamfm00U-lkW6JBoCUUMQAvD_BwE. Accessed on May 17, 2021.

Worldometers. Retrieved from worldometers.info: https:// www.worldometers.info/coronavirus/country/indonesia/. Accessed on May 17, 2021.

\section{$\underline{\text { Statutory Law and Regulation }}$}


Herzien Inlandsch Reglement (HIR)

Rechtreglement voor de Buitengewesten (RBG)

Law Number 30 of 2014 on Government Administration

Law Number 2 of 2020 on the Stipulation of Government Regulation in Lieu of Law Number 1 of 2020 concerning State Financial Policy and Financial System Stability for Handling the Corona Virus Disease 2019 (Covid-19) Pandemic and/or in the Context of Facing Threats That Endanger the National Economy and/or Financial System Stability Into Law

Law Number 48 of 2009 on Judicial Power

Law Number 49 of 2009 on the Second Amendment of the Law Number 2 of 1986 on General Court

Law Number 51 of 2009 on the Second Amendment of the Law Number 5 of 1986 on State Administrative Court

Indonesia Civil Code

Supreme Court Regulation Number 2 Year 2019 Guidance Dispute Settlement Mechanism of Government Action and Competence to Adjudicate Government Tort

Court Decision Number 99/G/2020/PTUN-JKT

Court Decision Number 230/G/TF/2019/PTUN-JKT

Court Decision Number 53/PDT.G/2012/PN.JKT.PST

Court Decision Number 118/Pdt.G.LH/ 2016/PN.Plk 